\title{
Minimal effective dose of lactic-fermented egg white on visceral fat in Japanese men: a double-blind parallel-armed pilot study
}

\author{
Ryosuke Matsuoka ${ }^{1 *}$ D, Keiko Kamachi ${ }^{2}$, Mika Usuda ${ }^{1}$, Yasunobu Masuda ${ }^{1}$, Masaaki Kunou', Akira Tanaka ${ }^{2}$ and \\ Kazunori Utsunomiya ${ }^{3}$
}

\begin{abstract}
Background: We previously reported that the consumption of $8 \mathrm{~g}$ of protein per day in the form of lactic-fermented egg white (LAFEW) improves visceral fat obesity. In this study, we investigated the minimum effective intake of LAFEW for visceral fat reduction in the Japanese males with mild obesity.

Methods: Twenty-two Japanese adult males with a Body mass index (BMI) $\geq 24$ and a waist circumference $\geq 85 \mathrm{~cm}$ were included in this study. The subjects were divided into three groups, that is, control group, LAFEW $6 \mathrm{~g}$ group, and LAFEW $8 \mathrm{~g}$ group. The LAFEW 6 and $8 \mathrm{~g}$ groups consumed 6 and $8 \mathrm{~g}$, respectively, of egg white protein (EWP) in a drink at breakfast for 8 weeks, whereas the control group consumed a drink containing $8 \mathrm{~g}$ of milk whey protein. Body weight, body fat percentage, abdominal circumference, and visceral fat (VF) area around the navel were measured at 0 and 8 weeks after initiating the consumption.
\end{abstract}

Results: No changes in body weight or body fat percentage were observed in any of the groups. No significant differences between the pre- and posttreatment measurements were found in the VF area around the navel in the control group and the LAFEW $6 \mathrm{~g}$ group. In the LAFEW $8 \mathrm{~g}$ group, the VF area had decreased significantly after 8 weeks of consumption, when compared to that before consumption, and the average observed decrease $\left(\Delta \mathrm{cm}^{2}\right)$ was $13.2 \pm 4.7 \mathrm{~cm}^{2}$. Among the subjects with an initial $\mathrm{BMI}>25$, the $V F$ area was significantly smaller in the LAFEW 8 group, when compared to the week 0 values and those in the control group. Visceral fat/subcutaneous fat values in the LAFEW 8 group were also significantly smaller than those in the control group or at week 0 .

Conclusion: The results suggested that the minimum effective intake of EWP in the LAFEW to reduce the VF area in the Japanese men is $8 \mathrm{~g}$.

Trial registration: This clinical trial was retrospectively registered with the University hospital Medical Information Network (UMIN) Center, (UMIN000031681; registered on 12/03/2018).

Keywords: Egg white, Visceral fat, Obesity, Japanese, Protein

\section{Introduction}

Egg white protein (EWP) has an amino acid score of 100 $[1,2]$, and has been reported to retain a high level of bioavailability even when not heated, or after half-boiling or heating cooking processes [3]. We have previously reported, in an animal experiment, that the consumption of

\footnotetext{
* Correspondence: ryosuke_matsuoka@kewpie.co.jp

${ }^{1}$ R\&D Division, Kewpie Corporation, 2-5-7 Sengawa Kewport, Sengawa-Cho,

Chofu-Shi, Tokyo 182-0002, Japan

Full list of author information is available at the end of the article
}

egg white protein increases the body's protein mass while decreasing the body fat and visceral fat [4].

However, egg white is difficult to intake as it is because of its flavor and physical properties. Therefore, we subjected the egg whites to lactic fermentation to develop a LAFEW that is easier to drink [5].

We previously reported that a daily intake of $8 \mathrm{~g}$ EWP by LAFEW for 12 weeks reduces the amount of visceral and visceral/subcutaneous fats and significantly relieves visceral fat obesity when compared to the preconsumption levels or control whey protein treatment [6]. The

(c) The Author(s). 2019 Open Access This article is distributed under the terms of the Creative Commons Attribution 4.0 International License (http://creativecommons.org/licenses/by/4.0/), which permits unrestricted use, distribution, and 
effects of less than $8 \mathrm{~g}$ daily intake of EWP on the reduction of visceral and visceral/subcutaneous fats remain unclear.

Similar to the egg white protein, lactoferrin and soybean-derived $\beta$-conglycinin have been reported to reduce visceral fat at daily intakes of $300 \mathrm{mg}$ and $5 \mathrm{~g}$, respectively [7, 8]. The inhibition of lipid absorption has been reported as a mechanism for the reduction of visceral fat by $\beta$-conglycinin [9], whereas the inhibition of lipid absorption by ovalbumin, ovotransferrin, and lysozyme has been reported as a mechanism underlying the visceral fat reduction effect of egg white protein $[10,11]$. To ingest $5 \mathrm{~g}$ as these 3 protein fractions, $8 \mathrm{~g}$ daily doses of EWP must be ingested [6, 12].

EWP is known to contain ovotransferrin, which has a similar function to that of lactoferrin. If ovotransferrin has an equivalent physiological activity as lactoferrin, an estimated daily intake of $3 \mathrm{~g}$ EWP should be sufficient to reduce visceral fat with LAFEW. Therefore, the minimum effective dose of EWP was hypothesized to be $3-8 \mathrm{~g}$ per day.

In a study investigating the effects of LAFEW on serum cholesterol levels, an 8-week daily consumption of $8 \mathrm{~g}$ EWP reduced the total and LDL cholesterol in serum to levels significantly lower than those before intake $(-4.7,-9.2 \%$, respectively) or after consumption of the $4 \mathrm{~g}$ daily intake group [13]. After 8 weeks of daily consumption of $6 \mathrm{~g}$ of EWP, serum LDL-cholesterol concentrations were also significantly lower than those before consumption $(-2.5,-6.4 \%$, respectively) [13]. No changes were observed in the total and LDL cholesterol levels in serum when a daily dose of $4 \mathrm{~g}$ of EWP was used $(+1.6 \%,-1.3 \%$, respectively) [13].

Therefore, the 8-week consumption of EWP at a daily intake of $6 \mathrm{~g}$ was anticipated to reduce visceral fat as it had previously improved lipid metabolism.

In this study, we evaluated the minimum effective daily intake dose for visceral fat reduction in humans using LAFEW preparations containing 6 and $8 \mathrm{~g}$ of EWP.

\section{Methods}

\section{Test food}

The control whey protein drink and the drink containing LAFEW were prepared at R\&D Division, Kewpie Corporation., Tokyo. Each drink was prepared by adding flavor, sweetener, water, etc., to milk whey (Nippon Shinyaku Co., Ltd., Kyoto) or LAFEW [5] (Kewpie Egg Corporation, Tokyo), by uniform mixing of the solution and heat-sterilizing. Nutritional value of whey drink and LAFEW drink were same (Energy 64 and $60 \mathrm{kcal} / 100 \mathrm{~g}$, protein 4.4 and $4.5 \mathrm{~g} / 100 \mathrm{~g}$, Lipids 0.4 and $0.1 \mathrm{~g} / 100 \mathrm{~g}$, Carbohydrate 10.8 or $10.5 \mathrm{~g} / 100 \mathrm{~g}$, respectively). The protein content of LAFEW or whey drink was determined using the Kjeldahl method [14], and we measured $8 \mathrm{~g}$ protein (EWP)/180 $\mathrm{g}$ in the control drink and LAFEW $8 \mathrm{~g}$ drink and as $6 \mathrm{~g}$ protein (EWP)/135 g for the LAFEW $6 \mathrm{~g}$ drink. Ovalbumin content in LAFEW was assessed by the sandwich ELISA procedure using an anti-chicken ovalbumin polyclonal antibody, followed with a horseradish peroxidase-labeled anti-chicken ovalbumin polyclonal antibody. We used the commercial Egg (Ovalbumin) ELISA kit II (Morinaga Institute of Biological Science Inc., Yokohama, Japan) at a detection absorbance of $450 \mathrm{~nm}$ using a multidetection microplate reader (Powerscan ${ }^{\circ}$ HT, DS Pharma Biomedical Co. Ltd., Osaka, Japan). Observed ovalbumin content in our LAFEW drink using the sandwich ELISA was $3.92 \mathrm{~g} / 180 \mathrm{~g}$.

\section{Subjects and test methods}

Twenty-two adult males with a BMI $>24$ and a waist circumference of $>85 \mathrm{~cm}$ served as subjects in this study. The subjects did not undergo treatment for hyperlipidemia or diabetes, had no subjective symptoms of gout, were capable of visiting the designated institution as scheduled, and were able to fill the forms required for the study, such as self-diagnosis forms. The exclusion criteria were as follows: intake of medications that could potentially affect the test results (e.g., antihyperlipidemic agents, antidiabetic agents, oral corticosteroid formulations, or antihypertensive agents); regular consumption of foods for specified health uses that could potentially affect the test results; excessive alcohol consumption; suspected allergic reactions (particularly to egg and milk); participation in other clinical studies; a history of serious liver damage, kidney damage, or myocardial infarction; a history of, or present condition of, hepatitis; and serious anemia.

The subjects were divided into three groups: the control group, the LAFEW $6 \mathrm{~g}$ group, and the LAFEW $8 \mathrm{~g}$ group. The subjects in the control group, LAFEW $6 \mathrm{~g}$ group, and LAFEW $8 \mathrm{~g}$ group consumed a milk whey drink for breakfast for 8 weeks ( $8 \mathrm{~g}$ of whey protein), LAFEW with $6 \mathrm{~g}$ of EWP, or LAFEW with $8 \mathrm{~g}$ of EWP, respectively.

Abdominal CT scans (SOMATOM Emotion ${ }^{\text {tw }}$, Siemens Healthcare K.K., Tokyo, Japan) were performed at weeks 0 and 12 of the study to measure the visceral fat deposits around the navel (Fat Scan, East Japan Institute of Technology Co., Ltd., Ibaraki, Japan). CT scans were performed at Kobayashi Hospital (Tokyo). At weeks 0 and 8, the subjects underwent fasting for at least $10 \mathrm{~h}$ before the blood samples were collected from a forearm vein and measurements were taken for body weight, body fat percentage, blood pressure, and abdominal circumference. A meal survey was conducted 3 days before blood sampling at weeks 0 and 8 to confirm that the nutritional intake remained unchanged.

\section{Blood analysis}

General peripheral blood tests were performed using flow cytometry. Sera were used to measure the following 
components: total cholesterol (enzymatic method), HDL-cholesterol (direct method), triglycerides (enzymatic method), free fatty acids (enzymatic method), phospholipids (enzymatic method), glucose (hexokinase UV method), HbA1c (latex agglutination method), RLP-cholesterol (immunosorbent method), insulin (CLEIA method), AST (JSCC standardization compatible method), ALT (JSCC standardization compatible method), $\gamma$-GTP (JSCC standardization compatible method), urea nitrogen (urease.LED.UV method), creatinine (enzymatic method), and uric acid (enzymatic method). LDL-cholesterol was calculated using Friedwald's equation [15]. Blood tests were conducted at SRL Inc. (Tokyo).

\section{Dietary analysis}

Our meal analysis comprised subjects reporting the contents of their meals for 3 days to calculate nutrition. Excel Eiyoukun ver. 5 (Kenpakusha, Tokyo) was used to perform the nutrition calculations. The 2010 Standard Tables of Food Composition in Japan was used as a database of the nutrition calculation software.

\section{Statistical analysis}

The test results were expressed in the form of a mean \pm standard error. The paired t-test and Dunnett's test were used to compare the treatment measurements with control and pretreatment measurements. Differences with a hazard ratio of less than $5 \%$ were considered to be statistically significant. Statistical analyses were performed using SPSS ver. 20 (SPSS Co., Ltd.).

\section{Results}

\section{Subject background}

No significant differences in age, body height, body weight, BMI, and systolic and diastolic blood pressure values were found among the three groups of subjects, confirming adequate group distribution (Table 1). All subjects successfully completed the study, with no withdrawals; however, certain inconsistencies were observed among the subjects; in the control group, one subject

Table 1 Background of Subjects

\begin{tabular}{llll}
\hline & Control & LAFEW 6 g & LAFEW 8g \\
\hline Age $(\mathrm{y})$ & $53.2 \pm 3.1$ & $54.9 \pm 2.2$ & $52.2 \pm 3.2$ \\
Height $(\mathrm{cm})$ & $174 \pm 2$ & $171 \pm 1$ & $172 \pm 2$ \\
Body weight $(\mathrm{kg})$ & $80.3 \pm 2.8$ & $76.6 \pm 2.5$ & $83.6 \pm 3.7$ \\
BMl & $26.6 \pm 0.9$ & $26.3 \pm 0.8$ & $28.5 \pm 1.5$ \\
Systolic blood presure $(\mathrm{mmHg})$ & $142 \pm 6$ & $147 \pm 6$ & $146 \pm 10$ \\
Diastolic blood pressure $(\mathrm{mmHg})$ & $86.6 \pm 3.9$ & $94.0 \pm 3.0$ & $90.2 \pm 6.4$
\end{tabular}

Mean \pm SE of 5 (Control), 7 (LAFEW $6 \mathrm{~g}$ ), or 6 (LAFEW $8 \mathrm{~g}$ )

Control: Control group, LAFEW 6 g: LAFEW $6 \mathrm{~g}$ group, LAFEW $8 \mathrm{~g}$ : LAFEW

$8 \mathrm{~g}$ group

LAFEW Lactic-fermented egg white exercised excessively and one subject's CT imaging resulted in an error, and in the LAFEW $8 \mathrm{~g}$ group, one subject had low VF area $\left(53.6 \mathrm{~cm}^{2}\right)$ at the commencement of the study and one subject was prescribed a cholesterol-lowering drug by a physician during the study period. Therefore, these subjects were excluded from the analyses. As a result, analyses included 5 subjects in the control group, 7 subjects in the LAFEW $6 \mathrm{~g}$ group, and 6 subjects in the LAFEW 8 g group (Fig. 1).

\section{Dietary analysis}

Significant changes in nutrition intake were observed over the course of the study period. In the LAFEW $6 \mathrm{~g}$ group, the carbohydrate intake decreased significantly from the preconsumption values; however, no significant changes in the energy intake were noted between the pre- and postconsumption levels. In the control group, salt intake increased significantly from the preconsumption values; however, a causal relationship between salt intake and visceral fat accumulation has not been reported, and no significant increases were observed in the blood pressure values, which we presumed to have been affected by the salt intake.

In both LAFEW groups ( 6 and $8 \mathrm{~g}$ ), energy and protein intake at week 8 were significantly lower than the respective values in the control group. The dietary fiber intake in the LAFEW $6 \mathrm{~g}$ group was significantly lower than that in the control group, and the cholesterol intake in the LAFEW $8 \mathrm{~g}$ group was significantly lower than that in the control group; however, no significant differences were observed in the dietary fiber and cholesterol intake in these groups between weeks 0 and 8 , and no significant changes in intake were observed over the course of the study (Table 2). We calculated change $\%$ of dietary intake.

\section{Physical condition}

For all items, no significant differences in physical condition were noted between weeks 0 and 8 or between the control group and the LAFEW 6 or $8 \mathrm{~g}$ groups (Table 3 ).

\section{Visceral fat area (Table 3)}

No significant differences from the preconsumption values were found among the three groups while measuring the total and subcutaneous fat area. In addition, no significant differences were observed in total and VF area between the LAFEW 6 or $8 \mathrm{~g}$ groups and the control group (Table 3).

The LAFEW $8 \mathrm{~g}$ group revealed significantly reduced VF area over the course of the study, with a mean decrease of $13.2 \mathrm{~cm}^{2}$, whereas no significant differences from the preconsumption values were found in the control and the LAFEW $6 \mathrm{~g}$ groups. No significant differences in the VF area were found among the three 


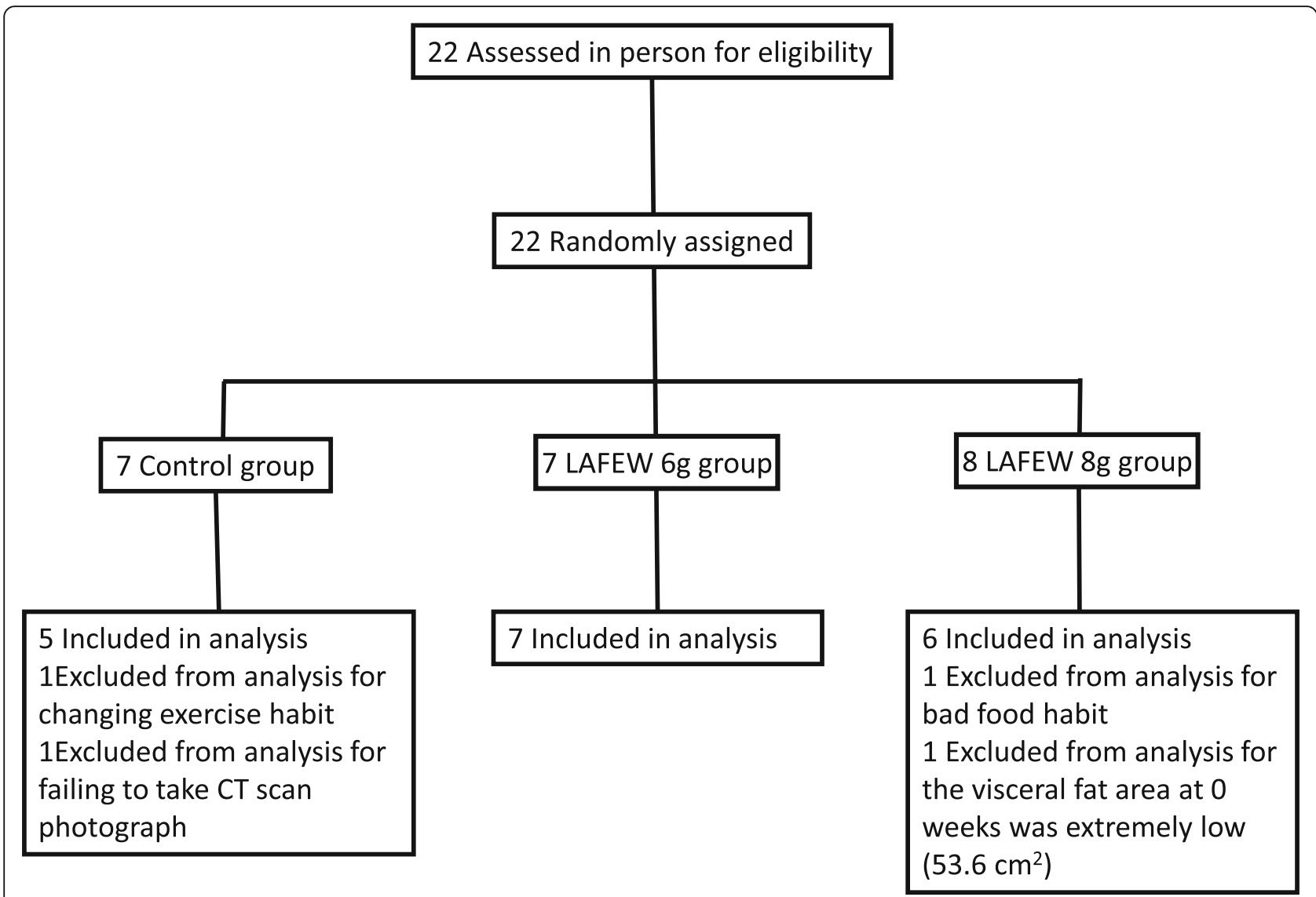

Fig. 1 Participant flow through a randomized trial

groups. The LAFEW $8 \mathrm{~g}$ group revealed significantly reduced visceral/subcutaneous fat over the course of the study, whereas no significant differences were observed in the control and the LAFEW $6 \mathrm{~g}$ groups. In addition, no significant differences in total fat area and VF area were noted between the LAFEW 6 or $8 \mathrm{~g}$ groups and the control group (Table 3).

The stratified analysis in the subjects with a BMI $>25$ revealed that the VF area and visceral fat/subcutaneous fat in the LAFEW $8 \mathrm{~g}$ group were significantly reduced compared to the values in the control group or at week 0 . The visceral fat/subcutaneous fat measurements in the LAFEW $6 \mathrm{~g}$ group were significantly lower than that in the control group, but not significantly different from the week 0 value (Figs. 2 and 3).

We excluded the patients diagnosed with obesity, impaired glucose tolerance, dyslipidemia and hypertension in this study and reanalysis was conducted to prevent the metabolic syndrome. In the LAFEW $8 \mathrm{~g}$ group $(n=3)$, the change in the VF area $(\Delta \mathrm{cm}$ [2]) around the umbilicus was $-18.4 \pm 4.9 \mathrm{~cm}^{2}$, which was significantly lower than before treatment and that of the control group $(n=3,+6.7 \pm$ $\left.6.2 \mathrm{~cm}^{2}\right)$ and the LAFEW 6 g group $\left(n=4,+5.3 \pm 5.3 \mathrm{~cm}^{2}\right)$.

\section{Hematological tests}

In the control group, the mean corpuscular volume (MCV) was significantly higher and mean corpuscular hemoglobin concentration (MCHC) was significantly lower, compared to the respective values before treatment. In the LAFEW $8 \mathrm{~g}$ group, the red blood cell counts ( $\mathrm{RBC})$, hemoglobin $(\mathrm{Hb})$, and $\mathrm{MCHC}$ values were significantly reduced and $\mathrm{MCHC}$ was significantly increased, compared to the pretreatment values; however, all hematological values measured remained within the respective normal ranges (Table 4). No change in the results of Hematological tests in the LAFEW $6 \mathrm{~g}$ group (Table 4).

\section{Serum lipid levels}

No significant changes were observed in the serum levels of total cholesterol, HDL-cholesterol, LDL-cholesterol, RLP-cholesterol, triglycerides, phospholipids, and free fatty acids. In the LAFEW $6 \mathrm{~g}$ group, HbA1c measurements were significantly higher than that in the pretreatment levels; however, the glucose levels were also significantly lower (Table 5). 
Table 2 Dietary Intake of Subjects

\begin{tabular}{|c|c|c|c|c|}
\hline & & Intake Perioc & s (Weeks) & \\
\hline & & 0 & 8 & \\
\hline Energy (kcal) & Control & $2114 \pm 126$ & $2303 \pm 94$ & $113 \pm 5$ \\
\hline & LAFEW $6 \mathrm{~g}$ & $1857 \pm 59$ & $1698 \pm 96 \#$ & $91.6 \pm 5.1$ \\
\hline & LAFEW $8 \mathrm{~g}$ & $2048 \pm 144$ & $1850 \pm 97 \#$ & $92.7 \pm 7.7$ \\
\hline Protein (g) & Control & $71.6 \pm 7.7$ & $84.5 \pm 2.0$ & $127 \pm 13$ \\
\hline & LAFEW $6 \mathrm{~g}$ & $71.3 \pm 4.3$ & $60.9 \pm 4.1 \#$ & $87.4 \pm 8.4$ \\
\hline & LAFEW $8 \mathrm{~g}$ & $81.1 \pm 7.1$ & $65.0 \pm 7.5 \#$ & $83.5 \pm 11.0$ \\
\hline Lipids (g) & Control & $71.4 \pm 6.4$ & $78.7 \pm 6.6$ & $119 \pm 11$ \\
\hline & LAFEW $6 \mathrm{~g}$ & $56.6 \pm 4.4$ & $56.5 \pm 7.0$ & $102 \pm 11$ \\
\hline & LAFEW $8 \mathrm{~g}$ & $71.2 \pm 6.0$ & $57.0 \pm 5.8$ & $94.7 \pm 11.8$ \\
\hline Carbohydrate (g) & Control & $278 \pm 15$ & $298 \pm 13$ & $109 \pm 4$ \\
\hline & LAFEW $6 \mathrm{~g}$ & $246 \pm 19$ & $213 \pm 23^{*} \#$ & $85.6 \pm 4.3 \#$ \\
\hline & LAFEW $8 \mathrm{~g}$ & $262 \pm 27$ & $261 \pm 13$ & $104 \pm 10$ \\
\hline Cholesterol (mg) & Control & $367 \pm 91$ & $439 \pm 63$ & $170 \pm 52$ \\
\hline & LAFEW $6 \mathrm{~g}$ & $328 \pm 30$ & $324 \pm 43$ & $101 \pm 12$ \\
\hline & LAFEW $8 \mathrm{~g}$ & $285 \pm 35$ & $235 \pm 30 \#$ & $93.4 \pm 22$ \\
\hline Dietary fiber (g) & Control & $13.2 \pm 2.1$ & $12.7 \pm 1.6$ & $102 \pm 9$ \\
\hline & LAFEW $6 \mathrm{~g}$ & $10.5 \pm 1.1$ & $8.97 \pm 0.97 \#$ & $87.1 \pm 7.7$ \\
\hline & LAFEW $8 \mathrm{~g}$ & $12.2 \pm 1.8$ & $10.2 \pm 1.1$ & $87.7 \pm 8.5$ \\
\hline
\end{tabular}

Mean \pm SE of 5 (Control), 7 (LAFEW $6 \mathrm{~g}$ ), or 6 (LAFEW $8 \mathrm{~g}$ )

Control: Control group, LAFEW $6 \mathrm{~g}$ : LAFEW $6 \mathrm{~g}$ group, LAFEW $8 \mathrm{~g}$ : LAFEW $8 \mathrm{~g}$ group

${ }^{*} p<0.05$ vs. 0 week by paired $t$-test, $\# p<0.05$ vs. Control by Dunnett test LAFEW Lactic-fermented egg white

\section{Hepatic and renal function indices}

In the LAFEW $6 \mathrm{~g}$ group, creatinine measurements were significantly higher than that before consumption. The blood urea nitrogen (BUN) measurements in the LAFEW $6 \mathrm{~g}$ group were significantly lower than that in the control group; however, these values were within the respective normal ranges. For other items, no effects of the test foods were observed (Table 6).

\section{Discussion}

In the present study, 8 weeks of daily consumption of LAFEW with $8 \mathrm{~g}$ of EWP was demonstrated to significantly decrease the VF area and visceral fat/subcutaneous fat in subjects with a BMI > 25 compared to the values before consumption or the control group that consumed milk whey protein. When LAFEW was consumed at a daily intake of $6 \mathrm{~g}$ as EWP, VF area was not significantly lower than that in the control subjects who consumed whey. A previous double-blinded, placebo-controlled study had reported similar results, indicating that the minimum effective amount of EWP is $8 \mathrm{~g} /$ day [6].

In the present study, 8 weeks of consumption of LAFEW was found to decrease the VF area by $13.2 \mathrm{~cm}^{2}$. A previous study also revealed an $8.9-\mathrm{cm}^{2}$ decrease in
Table 3 Results of Body Composition

\begin{tabular}{|c|c|c|c|c|}
\hline & & \multicolumn{2}{|c|}{ Intake Periods (Weeks) } & \multirow{2}{*}{$\begin{array}{l}\text { Change } \\
(\%)\end{array}$} \\
\hline & & 0 & 8 & \\
\hline \multirow[t]{3}{*}{ Body weight (kg) } & Control & $80.3 \pm 2.8$ & $80.7 \pm 2.8$ & $101 \pm 1$ \\
\hline & LAFEW $6 \mathrm{~g}$ & $76.6 \pm 2.5$ & $76.8 \pm 2.3$ & $100 \pm 1$ \\
\hline & LAFEW $8 \mathrm{~g}$ & $83.6 \pm 3.7$ & $83.2 \pm 4.2$ & $100 \pm 1$ \\
\hline \multirow[t]{3}{*}{ BMl } & Control & $26.6 \pm 0.9$ & $26.7 \pm 0.9$ & $101 \pm 1$ \\
\hline & LAFEW $6 \mathrm{~g}$ & $26.3 \pm 0.8$ & $26.3 \pm 0.7$ & $100 \pm 1$ \\
\hline & LAFEW $8 \mathrm{~g}$ & $28.5 \pm 1.5$ & $28.4 \pm 1.7$ & $100 \pm 1$ \\
\hline \multirow[t]{3}{*}{ Waist (cm) } & Control & $95.6 \pm 2.1$ & $95.2 \pm 2.4$ & $99.6 \pm 0.8$ \\
\hline & LAFEW $6 \mathrm{~g}$ & $93.8 \pm 1.5$ & $92.8 \pm 1.8$ & $99.0 \pm 0.6$ \\
\hline & LAFEW $8 \mathrm{~g}$ & $98.5 \pm 1.7$ & $97.0 \pm 2.1$ & $98.4 \pm 0.8$ \\
\hline \multirow{3}{*}{$\begin{array}{l}\text { Total fat area } \\
\left(\mathrm{cm}^{2}\right)\end{array}$} & Control & $315 \pm 42$ & $316 \pm 44$ & $101 \pm 3$ \\
\hline & LAFEW $6 \mathrm{~g}$ & $310 \pm 15$ & $317 \pm 16$ & $103 \pm 3$ \\
\hline & LAFEW $8 \mathrm{~g}$ & $365 \pm 37$ & $358 \pm 38$ & $98.0 \pm 2.7$ \\
\hline \multirow{3}{*}{$\begin{array}{l}\text { Subcutaneous } \\
\text { fat area }\left(\mathrm{cm}^{2}\right)\end{array}$} & Control & $179 \pm 17$ & $179 \pm 17$ & $100 \pm 1$ \\
\hline & LAFEW $6 \mathrm{~g}$ & $160 \pm 18$ & $168 \pm 20$ & $104 \pm 2$ \\
\hline & LAFEW $8 \mathrm{~g}$ & $223 \pm 26$ & $230 \pm 29$ & $103 \pm 3$ \\
\hline \multirow{3}{*}{$\begin{array}{l}\text { Visceral fat area } \\
\left(\mathrm{cm}^{2}\right)\end{array}$} & Control & $137 \pm 28$ & $137 \pm 29$ & $102 \pm 8$ \\
\hline & LAFEW $6 \mathrm{~g}$ & $149 \pm 18$ & $149 \pm 16$ & $101 \pm 4$ \\
\hline & LAFEW $8 \mathrm{~g}$ & $141 \pm 14$ & $128 \pm 15^{*}$ & $89.9 \pm 3.8$ \\
\hline \multirow{3}{*}{$\begin{array}{l}\text { Visceral fat/ } \\
\text { Subcutaneous fat }\end{array}$} & Control & $0.753 \pm 0.115$ & $0.743 \pm 0.100$ & $101 \pm 8$ \\
\hline & LAFEW $6 \mathrm{~g}$ & $1.03 \pm 0.19$ & $0.994 \pm 0.189$ & $96.4 \pm 1.9$ \\
\hline & LAFEW $8 \mathrm{~g}$ & $0.647 \pm 0.051$ & $0.577 \pm 0.064^{*}$ & $88.2 \pm 4.5$ \\
\hline
\end{tabular}

Mean \pm SE of 5 (Control), 7 (LAFEW $6 \mathrm{~g}$ ), or 6 (LAFEW 8g)

Control: Control group, LAFEW 6g: LAFEW $6 \mathrm{~g}$ group, LAFEW 8g: LAFEW $8 \mathrm{~g}$ group

${ }^{*} p<0.05$ vs. 0 weeks by paired t-test

LAFEW Lactic-fermented egg white

the VF area over the course of a 12-week treatment with daily LAFEW containing $8 \mathrm{~g}$ of EWP. Food ingredients reported to reduce visceral fat include catechin [16] and polyphenols [17], and the visceral fat reduction observed under catechin and polyphenol treatments are -6.5 and $9.4 \mathrm{~cm}^{2}$, respectively. Thus, the LAFEW was reported to have a visceral fat-reducing effect equal to or more potent than the functional ingredients known to reduce visceral fat.

In the present study, the visceral fat-reduction effect was observed even in a shorter treatment period compared to that in the previous study. The visceral fat-reduction effect of lactoferrin appears on 8 weeks [8] and the results from the present study suggest that LAFEW has a comparable level of efficacy.

Subjects in this study included few individuals with BMI $<25$. When all the subjects were included in the analysis, the LAFEW did not decrease visceral fat compared to the control drink; however, the analysis 


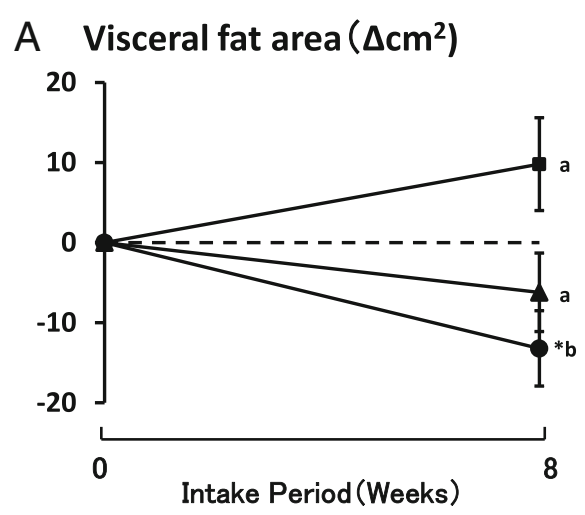

\section{B Visceral/Subcutaneous $(\Delta)$}

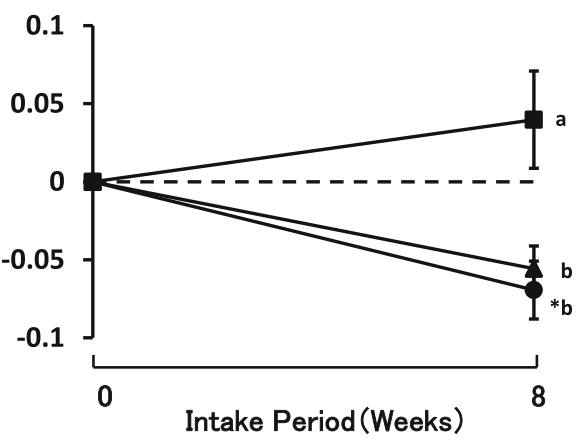

Fig. 2 Change in VF area and ratio of visceral to subcutaneous fat area (BMI > 25). Mean \pm SE of 4 (control), 4 (LAFEW $6 \mathrm{~g})$, and 6 (LAFEW $8 \mathrm{~g})$, a: results of Visceral fat area $(\Delta \mathrm{cm} 2)$, b: Result of Visceral fat/Subcutaneous fat $(\Delta), \mathbf{m}$ : Control group, $\boldsymbol{\Delta}$ : LAFEW $6 \mathrm{~g} g r o u p, \bullet: L A F E W \quad 8 \mathrm{~g}$ group, *: $p<0.05$ vs. 0 weeks by paired $t$-test, Diffecent letters shown a significant Difference by Dunnett test $(p<0.05)$

in subjects with $\mathrm{BMI} \geq 25$ revealed a decrease in the VF area, suggesting that LAFEW is more effective in obese individuals than in the healthy individuals. The visceral fat-reducing effect in subjects with BMI $>25$ has also been demonstrated in studies of catechin and oolong-tea polyphenols $[18,19]$. Apart from visceral fat, the individuals with higher serum levels of total and LDL cholesterol have been reported to have more dramatic results when treated with the functional foods to reduce fat, and the present results are consistent with this finding. Since the metabolic syndrome is often attributed to disturbed eating habits, functional ingredients are presumably less effective for healthy individuals who have regular eating habits and more effective for individuals who have abnormal eating habits [20].

The observed minimum effective amount of EWP consumed to reduce visceral fat was $8 \mathrm{~g}$, suggesting a mechanism closer to that of $\beta$-conglycinin, rather than that of lactoferrin. The $\beta$-conglycinin is known to suppress lipid absorption, which is the hypothesized mechanism of visceral fat-reduction [9], whereas egg white protein has been similarly reported to suppress lipid absorption. The major components of egg white protein are ovalbumin, ovotransferrin, and lysozyme [10], and its efficacy, albeit in an in vitro study, was comparable. Therefore, the ingredient primarily responsible for suppression of lipid absorption is hypothesized to be ovalbumin, based on its proportion found in egg white. Furthermore, $\beta$-oxidation of egg white protein in the liver also increased [4], and we assumed that multiple mechanisms are presumably involved in the visceral fat-reducing effect of LAFEW $[4,9]$.

In this study, subjects in the control group consumed $8 \mathrm{~g}$ of milk whey protein daily, which contains approximately $450 \mathrm{mg}$ of lactoferrin. This amount should be
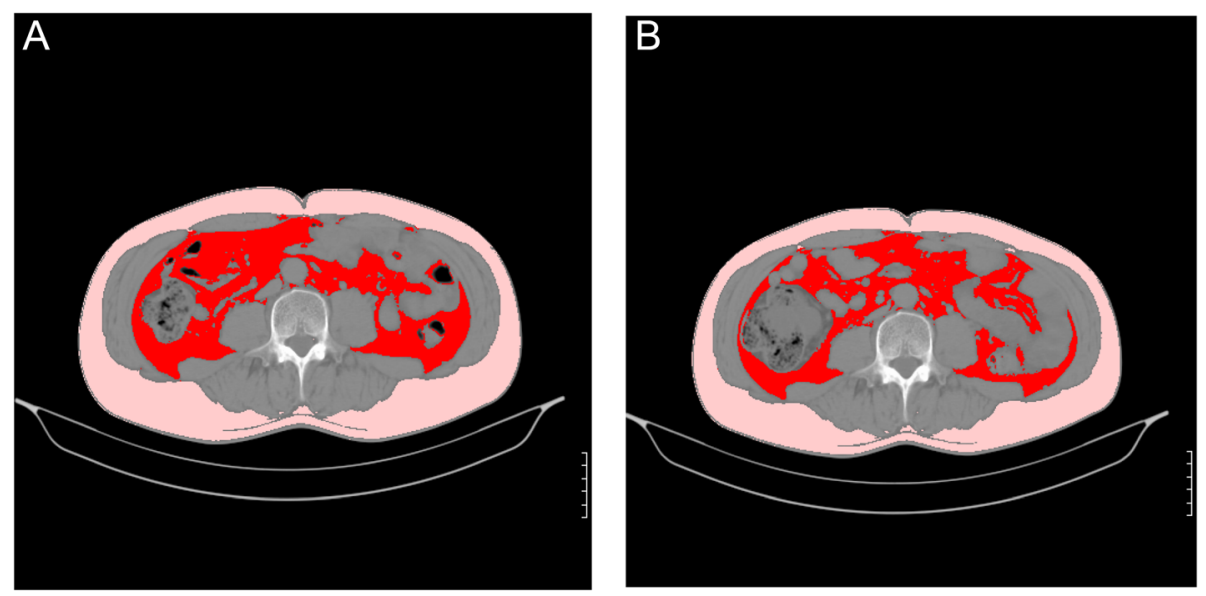

Fig. 3 Representative CT scans demonstrating the change in visceral fat area (VFA) of the subjects fed lactic-fermented egg white (8 $\mathrm{g}$ as protein) for 8 weeks. Red: Visceral fat, Pink: Subcutaneous fat. a: Pre-intake $\left(V F\right.$ area $\left.=107 \mathrm{~cm}^{2}\right)$, b: Post-intake $\left(V F\right.$ area $\left.=89 \mathrm{~cm}^{2}\right)$ 
Table 4 Results of Hematological Tests

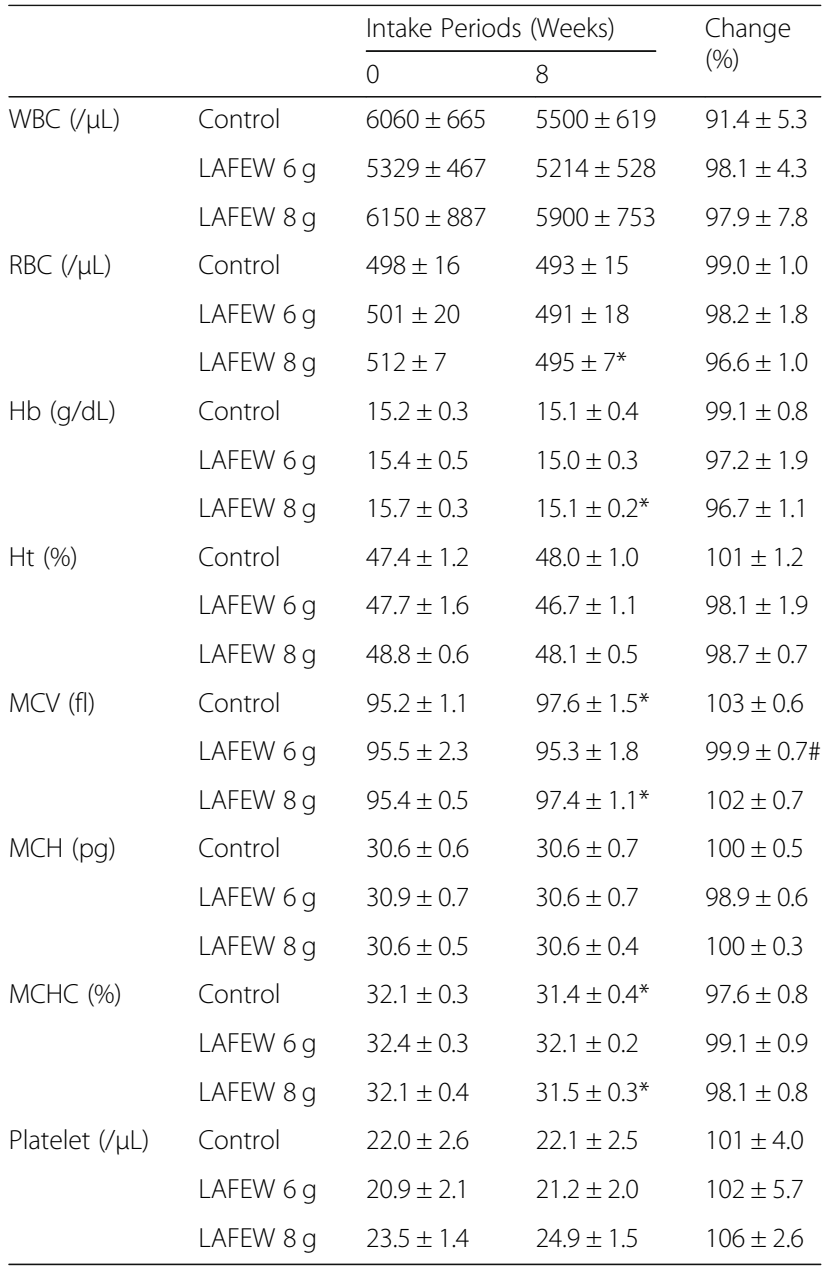

Mean \pm SE of 5 (Control), 7 (LAFEW $6 \mathrm{~g}$ ), or 6 (LAFEW $8 \mathrm{~g}$ )

Control: Control group, LAFEW 6 g: LAFEW $6 \mathrm{~g}$ group, LAFEW $8 \mathrm{~g}$ : LAFEW $8 \mathrm{~g}$ group

${ }^{*} p<0.05$ vs. 0 week by paired $t$-test, $\# p<0.05$ vs. Control by Dunnett test LAFEW Lactic-fermented egg white

sufficient to reduce visceral fat; however, we did not observe a reduction in visceral fat in the control group. We hypothesize that other proteins in the whey protein may be competing with lactoferrin. Previously, it was reported that consumption of milk whey at even $28 \mathrm{~g} /$ day had no effects on visceral fat [21].

The results from the present study involve data for Japanese subjects. Because metabolism differs in diverse genetic backgrounds and with different lifestyles, some optimization of the treatment may be required for it to be successful in diverse populations, including the United States and Europe. Some major cultural differences are potentially lipid intake and BMI. Japanese men with a BMI $>25$ are classified as obese, whereas men with BMI $>30$ are considered as obese in the United States [22, 23]. The average lipid intake is $62 \mathrm{~g}$ among the Japanese men, whereas it is $95 \mathrm{~g}$ in the adult males in the United States
Table 5 Serum Biochemical Analysis

\begin{tabular}{|c|c|c|c|c|}
\hline & & \multicolumn{2}{|c|}{ Intake Periods (Weeks) } & \multirow{2}{*}{$\begin{array}{l}\text { Change } \\
(\%)\end{array}$} \\
\hline & & 0 & 8 & \\
\hline \multirow{3}{*}{$\begin{array}{l}\text { Total Cholesterol } \\
(\mathrm{mg} / \mathrm{dL})\end{array}$} & Control & $200 \pm 5$ & $191 \pm 7$ & $95.4 \pm 2.6$ \\
\hline & LAFEW $6 \mathrm{~g}$ & $220 \pm 9$ & $211 \pm 6$ & $96.2 \pm 2.9$ \\
\hline & LAFEW $8 \mathrm{~g}$ & $250 \pm 12 \#$ & $229 \pm 21$ & $90.4 \pm 5.3$ \\
\hline \multirow{3}{*}{$\begin{array}{l}\text { HDL-Cholesterol } \\
\text { (mg/dL) }\end{array}$} & Control & $50.0 \pm 4.8$ & $51.4 \pm 3.2$ & $104 \pm 5$ \\
\hline & LAFEW $6 \mathrm{~g}$ & $49.7 \pm 3.3$ & $49.1 \pm 3.6$ & $98.8 \pm 3.6$ \\
\hline & LAFEW $8 \mathrm{~g}$ & $65.8 \pm 5.3$ & $56.8 \pm 7.6$ & $85.6 \pm 7.9$ \\
\hline \multirow{3}{*}{$\begin{array}{l}\text { LDL-Cholesterol } \\
(\mathrm{mg} / \mathrm{dL})\end{array}$} & Control & $134 \pm 5$ & $129 \pm 7$ & $95.0 \pm 3.2$ \\
\hline & LAFEW $6 \mathrm{~g}$ & $133 \pm 8$ & $134 \pm 5$ & $95.4 \pm 5.8$ \\
\hline & LAFEW $8 \mathrm{~g}$ & $160 \pm 12$ & $150 \pm 14$ & $88.5 \pm 5.8$ \\
\hline \multirow[t]{3}{*}{ Triglyceride (mg/dL) } & Control & $125 \pm 29$ & $103 \pm 16$ & $88.4 \pm 10.3$ \\
\hline & LAFEW $6 \mathrm{~g}$ & $250 \pm 57$ & $230 \pm 70$ & $99.7 \pm 18.1$ \\
\hline & LAFEW $8 \mathrm{~g}$ & $147 \pm 40$ & $166 \pm 34$ & $124 \pm 13$ \\
\hline \multirow[t]{3}{*}{ NEFA (mEq/L) } & Control & $536 \pm 103$ & $351 \pm 29$ & $74.3 \pm 13.5$ \\
\hline & LAFEW $6 \mathrm{~g}$ & $477 \pm 61$ & $498 \pm 110$ & $109 \pm 19$ \\
\hline & LAFEW $8 \mathrm{~g}$ & $431 \pm 62$ & $540 \pm 84$ & $116 \pm 15$ \\
\hline \multirow[t]{3}{*}{ Phospholipid (mg/dL) } & Control & $202 \pm 8$ & $192 \pm 4$ & $95.4 \pm 3.1$ \\
\hline & LAFEW $6 \mathrm{~g}$ & $234 \pm 12$ & $223 \pm 14$ & $95.2 \pm 2.4$ \\
\hline & LAFEW $8 \mathrm{~g}$ & $250 \pm 14 \#$ & $234 \pm 22$ & $91.9 \pm 5.6$ \\
\hline \multirow[t]{3}{*}{ Glucose (mg/dL) } & Control & $98.6 \pm 6.2$ & $97.8 \pm 9.9$ & $98.5 \pm 3.9$ \\
\hline & LAFEW $6 \mathrm{~g}$ & $99.4 \pm 3.0$ & $93.3 \pm 3.1^{*}$ & $93.9 \pm 1.9$ \\
\hline & LAFEW $8 \mathrm{~g}$ & $99.7 \pm 5.2$ & $95.8 \pm 4.3$ & $96.5 \pm 2.6$ \\
\hline \multirow[t]{3}{*}{$\mathrm{HbA} 1 \mathrm{c}(\%)$} & Control & $5.44 \pm 0.32$ & $5.72 \pm 0.47$ & $104 \pm 3$ \\
\hline & LAFEW $6 \mathrm{~g}$ & $5.13 \pm 0.18$ & $5.37 \pm 0.16^{*}$ & $105 \pm 2$ \\
\hline & LAFEW $8 \mathrm{~g}$ & $5.62 \pm 0.20$ & $5.65 \pm 0.18$ & $101 \pm 2$ \\
\hline \multirow{3}{*}{$\begin{array}{l}\text { RLP-Cholsterol } \\
\text { (mg/dL) }\end{array}$} & Control & $4.84 \pm 0.81$ & $3.80 \pm 0.26$ & $75.3 \pm 7.5$ \\
\hline & LAFEW $6 \mathrm{~g}$ & $8.90 \pm 1.79$ & $8.76 \pm 2.58$ & $107 \pm 22$ \\
\hline & LAFEW $8 \mathrm{~g}$ & $6.40 \pm 1.67$ & $5.05 \pm 0.94$ & $107 \pm 11$ \\
\hline
\end{tabular}

Mean \pm SE of 5 (Control), 7 (LAFEW $6 \mathrm{~g}$ ), or 6 (LAFEW $8 \mathrm{~g}$ )

Control: Control group, LAFEW $6 \mathrm{~g}$ : LAFEW $6 \mathrm{~g}$ group, LAFEW $8 \mathrm{~g}$ : LAFEW

$8 \mathrm{~g}$ group

${ }^{*} p<0.05$ vs. 0 week by paired $t$-test, $\# p<0.05$ vs. Control by Dunnett test LAFEW Lactic-fermented egg white

$[24,25]$ Considering these two cases, a man in the United States would need to consume an approximate daily intake of LAFEW of about $12 \mathrm{~g}$ EWP to reduce visceral fat.

In this study, we also measured the markers of hepatic and renal functions, and found no abnormal increases or decreases. Therefore, these data confirm that consumption at our dosage is safe.

In metabolic syndrome, obesity is thought to trigger pathogenic processes leading to hypertension, dyslipidemia, impaired glucose tolerance, and eventually, arteriosclerotic diseases. If we can proceed with this study and clarify the visceral fat-reducing effect of EWP, the quality of life of obese patients could be improved. We need to do two more 
Table 6 Results of Liver and Kidney Function

\begin{tabular}{|c|c|c|c|c|}
\hline & \multicolumn{2}{|c|}{ Intake Periods (Weeks) } & \multirow{2}{*}{$\begin{array}{l}\text { Change } \\
(\%)\end{array}$} \\
\hline & & 0 & 8 & \\
\hline \multirow[t]{3}{*}{ AST (IU/L) } & Control & $50.4 \pm 26.7$ & $35.2 \pm 12.3$ & $88.8 \pm 9.9$ \\
\hline & LAFEW $6 \mathrm{~g}$ & $21.9 \pm 1.9$ & $22.1 \pm 2.4$ & $101 \pm 5.4$ \\
\hline & LAFEW $8 \mathrm{~g}$ & $31.3 \pm 6.0$ & $28.7 \pm 4.4$ & $98.2 \pm 12.2$ \\
\hline \multirow[t]{3}{*}{$\mathrm{ALT}(\mathrm{IU} / \mathrm{L})$} & Control & $52.2 \pm 28.2$ & $45.4 \pm 21.7$ & $95.5 \pm 6.2$ \\
\hline & LAFEW $6 \mathrm{~g}$ & $22.0 \pm 2.8$ & $23.4 \pm 3.7$ & $105 \pm 7.2$ \\
\hline & LAFEW $8 \mathrm{~g}$ & $49.0 \pm 12.9$ & $39.0 \pm 10.5$ & $94.3 \pm 21.4$ \\
\hline \multirow[t]{3}{*}{ Y-GTP (IU/L) } & Control & $72.6 \pm 33.0$ & $74.6 \pm 35.5$ & $105 \pm 9.9$ \\
\hline & LAFEW $6 \mathrm{~g}$ & $70.6 \pm 21.3$ & $70.9 \pm 24.4$ & $96.7 \pm 5.8$ \\
\hline & LAFEW $8 \mathrm{~g}$ & $37.8 \pm 7.3$ & $33.7 \pm 7.3$ & $86.8 \pm 5.4$ \\
\hline \multirow[t]{3}{*}{ BUN (mg/dL) } & Control & $13.0 \pm 1.3$ & $14.2 \pm 0.9$ & $111 \pm 8.2$ \\
\hline & LAFEW $6 \mathrm{~g}$ & $12.5 \pm 1.1$ & $11.2 \pm 0.7 \#$ & $92.5 \pm 7.8$ \\
\hline & LAFEW $8 \mathrm{~g}$ & $12.8 \pm 0.5$ & $11.8 \pm 0.7$ & $91.9 \pm 4.3$ \\
\hline \multirow[t]{3}{*}{$\mathrm{Cr}(\mathrm{mg} / \mathrm{dL})$} & Control & $0.748 \pm 0.042$ & $0.752 \pm 0.039$ & $101 \pm 2$ \\
\hline & LAFEW $6 \mathrm{~g}$ & $0.779 \pm 0.029$ & $0.836 \pm 0.030^{*}$ & $108 \pm 3$ \\
\hline & LAFEW $8 \mathrm{~g}$ & $0.798 \pm 0.032$ & $0.823 \pm 0.024$ & $104 \pm 3$ \\
\hline \multirow[t]{3}{*}{ UA (mg/dL) } & Control & $6.34 \pm 0.15$ & $6.16 \pm 0.37$ & $97.7 \pm 7.4$ \\
\hline & LAFEW $6 \mathrm{~g}$ & $5.96 \pm 0.31$ & $5.83 \pm 0.30$ & $98.4 \pm 4.0$ \\
\hline & LAFEW $8 \mathrm{~g}$ & $6.12 \pm 0.47$ & $5.95 \pm 0.46$ & $98.1 \pm 5.6$ \\
\hline
\end{tabular}

Mean \pm SE of 5 (Control), 7 (LAFEW $6 \mathrm{~g}$ ), or 6 (LAFEW $8 \mathrm{~g}$ )

Control: Control group, LAFEW $6 \mathrm{~g}$ : LAFEW $6 \mathrm{~g}$ group, LAFEW 8 g: LAFEW $8 \mathrm{~g}$ group

${ }^{*} p<0.05$ vs. 0 week by paired $t$-test, $\# p<0.05$ vs. Control by Dunnett test LAFEW Lactic-fermented egg white

experiment to clarify the visceral fat reducing effect of EWP, using subject has different BMI and time dependent change in VS area (as if 2, 4, 6, 8 10,and 12 weeks). Furthermore, if the LAFEW, which is made easier to ingest than original egg white, was commercialized, it could promote public health and reduce visceral fat while allowing for the consumption of a high-quality protein source.

\section{Conclusion}

Minimum effective intake of EWP to reduce the VF area in the Japanese men is $8 \mathrm{~g}$ and LAFEW is more effective in obese individuals than healthy individuals.

\section{Abbreviations}

BMI: Body mass index; CT: Computed tomography; EWP: egg white protein; LAFEW: Lactic-fermented egg white; VF: Visceral fat

\section{Acknowledgments}

This study was supported entirely by a grant received from Kewpie Corporation, Japan. We thank Prof. Michihiro Sugano (Kyushu University, and Prefectural University of Kumamoto) for providing technical advice about this trial. The authors would like to thank Enago (www.enago.jp) for the English language review.

\section{Funding}

Experimental work in the Nutrition Clinic, Kagawa Nutrition University was supported by Kewpie Corporation (Tokyo, Japan).

\section{Availability of data and materials}

The dataset supporting the conclusions of this article is included within the article.

\section{Authors' contributions}

$\mathrm{RM}, \mathrm{KK}, \mathrm{MU}, \mathrm{YM}, \mathrm{MK}, \mathrm{AT}$, and $\mathrm{KU}$ approved the study concept and design. AT, as the principal investigator, was responsible for the study logistics, data acquisition, and RM and KK for manuscript preparation. KK, and MU were responsible for conducting the trial, data collection, and performing laboratory analysis. RM and AT carried out the statistical analysis. YM, MK, and KU supervised the study design and commented on the manuscript. All authors contributed to the intellectual content of the manuscript.

\section{Ethics approval and consent to participate}

This study was conducted in accordance with the Declaration of Helsinki, and with the approval of the Ethics Committee of Kagawa Education Institute of Nutrition (authorization no. 196; 14th March, 2012). Participants received a thorough explanation of the study protocol and those who provided consent were included. The study was conducted at the Nutritional Clinic of Kagawa Education Institute of Nutrition.

\section{Consent for publication}

Not applicable

\section{Competing interests}

KK, AT, and KU declare no conflict of interest. RM, MU, Y.M., and M.K. are employees of Kewpie Corporation. There are no other patents, products in development, or marketed products to declare.

\section{Publisher's Note}

Springer Nature remains neutral with regard to jurisdictional claims in published maps and institutional affiliations.

\section{Author details}

${ }^{1}$ R\&D Division, Kewpie Corporation, 2-5-7 Sengawa Kewport, Sengawa-Cho, Chofu-Shi, Tokyo 182-0002, Japan. ${ }^{2}$ Nutrition Clinic, Kagawa Nutrition University, Komagome, Toshima-ku, Tokyo 170-8481, Japan. ${ }^{3}$ Division of Diabetes, Metabolism \& Endocrinology, Jikei University School of Medicine, 3-25-8, Nishi-shinbashi, Minato-ku, Tokyo 105-8461, Japan.

Received: 6 August 2018 Accepted: 8 April 2019

Published online: 22 April 2019

\section{References}

1. WHO. Energy and protein requirements (WHO technical report series, no. 724). Report of a joint FAO/WHO/UNU expert consultation. Geneva: World Health Organization; 1985.

2. Attia YA, Al-Harthi MA, Shiboob MM. Evaluation of quality and nutrient contents of table eggs from different sources in the retail market. Ita J Anim Sci. 2014;13:369

3. Matsuoka R, Takahashi Y, Kimura M, Masuda Y, Kunou M. Heating has no effect on the net protein utilisation from egg whites in rats. Sci World J. 2017;2017:6817196.

4. Matsuoka R, Shirouchi B, Umegatani M, Fukuda M, Muto A, Masuda Y, et al. Dietary egg white protein increases body protein mass and reduces body fat mass through an acceleration of hepatic $\beta$-oxidation in rats. $\mathrm{Br} J$ Nutr. 2017;118:423-30.

5. Arimitsu K, Takashi K, Matsuoka R, Narita K, Idei A. The good function of lactic fermented egg white "Lacty egg". Jpn J Food Engineering. 2015;16: 79-82 (In Japanese).

6. Matsuoka R, Kamachi K, Usuda M, Wang W, Masuda Y, Kunou M, et al. Lacticfermented egg white improves visceral fat obesity in Japanese subjects—double-blind, placebo-controlled study. Lipids Health Dis. 2017;16:237.

7. Kohno M, Hirotsuka M, Kito M, Matsuzawa Y. Decreases in serum triglycerol and visceral fat mediated by dietary soybean beta-conglycinin. J Atheroscler Thromb. 2006;13:247-55.

8. Ono T, Murakoshi M, Suzuki N, lida N, Ohdera M, ligo M, et al. Potent antiobesity effect of enreric-coated lactoferrin: decrease in visceral fat accumulation in Japanese men and women with abdominal obesity after 8-week administration of enteric coated lactofferin tablets. Br J Nutr. 2010;104:1688-95. 
9. Moriyama T, Kishimoto K, Nagai K, Urade R, Ogawa T, Utsumi S, et al. Soybean beta-conglycinin diet suppresses serum triglyceride levels in normal and genetically obese mice by induction of beta-oxidation, downregulation of fatty acid synthase, and inhibition of triglyceride absorption. Biosci Biotechnol Biochem. 2004;68:352-9.

10. Matsuoka R, Shirouchi B, Kawamura S, Baba S, Shiratake S, Nagata K, et al. Dietary egg white protein inhibits lymphatic lipid transport in thoracic lymph duct-cannulated rats. J Agr Food Chem. 2014;62:10694-700.

11. Matsuoka R, Kimura M, Muto A, Masuda Y, Sato M, Imaizumi K. Mechanism for the cholesterol-lowering action of egg white protein in rats. Biosci Biotechnol Biochem. 2008;72:1506-12.

12. Nakamura R, Takeyama M, Nakamura K, Umemura O. Constituent proteins of globulin fraction obtained from egg white. Agrin Biol Chem. 1980;44: 2357-63.

13. Matsuoka R, Usuda M, Masuda Y, Kunou M, Utsunomiya K. Lactic-fermented egg white reduced serum cholesterol concentrations in mildly hypercholesterolemic Japanese men: a double-blind, parallel-arm design. Lipids Health Dis. 2017;16:101.

14. Stitcher JE, Jolliff CR, Hill RM. Comparison of dumas and Kjeldahl methods for determination of nitrogen in faces. Clin Chem. 1969;15:248-54.

15. Friedewald WT, Levy RI, Frederickson DS. Estimation of the concentration of low-density lipoprotein cholesterol in plasma, without use of the preparative ultracentrifuge. Clin Chem. 1972;18:499-502.

16. Nagao T, Hase T, Tokimitsu I. A green tea extract high in cathechins reduces body fat and cardiovascular risks in humans. Obesity. 2007;15:1473-83.

17. Akazome Y, Kametani N, Kanda T, Shimasaki H, Kobayashi S. Evaluation of safety of excessive intake and efficacy of long-term intake of beverages containing apple polyphenols. J Oleo Sci. 2010;59:321-38.

18. Maekawa T, Teramoto T, Nakamura J, Kitagawa Y, Shibata H, Tsuchida T. Effects of long-term inrtake of "KURO-oolong tea OTPP" on body fat mass and metabolic syndrome risk in over weight volunteers. Jpn Pharmacol Ther. 2011;39:889-900. (in Japanese).

19. Hase T, Komine Y, Meguro S, Takeda Y, Takahashi H, Matsui Y, et al. Antiobesity effects of tea Catechins in humans. J Oleo Sci. 2001;50:599-601 in Japanese.

20. Alkhatib A, Tsang C, Tiss A, Bahorun T, Arefanian H, Barake R, Khadir A, Tuomilehto J. Functional foods and lifestyle approaches for diabetes prevention and management. Nutrients. 2017;9:E1310.

21. Beer DJ, Stoke KS, Paul DR, Harris GK, Rumpler WW, Clevidence BA. Whey protein but not soy protein supplementation alters body weight and composition in free-living overweight and obese adults. J Nutr. 2011;141: 1489-94.

22. Examination Committee of Criteria for. 'Obesity Disease' in Japan. Japan society for the study of obesity: New criteria for 'obesity disease' in Japan. Circ J. 2002;66:987-92.

23. Clinical guidelines on the identification, evaluation, and treatment of overweight and obesity in adults: executive summary: Expert Panel on the Identification, Evaluation, and Treatment of Overweight in Adults. Am J Clin Nutr. 1998;68:899-917.

24. Ministry of Health, Labor, and Welfare, Japan. The National Nutrition Survey in Japan, 2015. http://www.mhlw.go.jp/stf/houdou/0000142359.html. , in Japanese.

25. What We Eat in America, NHANES 2013-2014, individuals 2 years and over (excluding breast-fed children), day 1. Available: www.ars.usda.gov/nea/bhnrc/fsrg. Accessed 1 Aug 2018

Ready to submit your research? Choose BMC and benefit from:

- fast, convenient online submission

- thorough peer review by experienced researchers in your field

- rapid publication on acceptance

- support for research data, including large and complex data types

- gold Open Access which fosters wider collaboration and increased citations

- maximum visibility for your research: over $100 \mathrm{M}$ website views per year

At $\mathrm{BMC}$, research is always in progress.

Learn more biomedcentral.com/submissions 